\title{
PERLINDUNGAN HUKUM EKSPEDITUR ATAS PENGIRIMAN PRODUK AGRIKULTURA BERDASARKAN SEA TRANSPORT AGREEMENT
}

\author{
Anik Wulandari \\ anikwulan76@gmail.com \\ Mahasiswa S1 Fakultas Hukum Universitas Sebelas Maret \\ Moch. Najib Imanullah \\ najibimanullah@staff.uns.ac.id \\ Dosen Fakultas Hukum Universitas Sebelas Maret
}

\begin{abstract}
This paper describes and examines the issues of how to protect against shipping companies contained in sea transport agreement agreements. The purpose of this paper is to know the legal protection of shipping companies contained in sea transport agreements. Data collection technique is literature study with statute approach method, the instrument of this research is the Book of Trade Law Act, Law Number 17 Year 2008 concerning Shipping and related legislation, as well as sea transport documents. The result of the research shows that every sea freight shipping company (EMKL) has procedures and requirements in transporting goods by sea, legal protection against shipping companies contained in sea transport agreement there are 2 (two) properties that is preventive and repressive. As a preventive measure, Legal Protection of the Expeditor from the delivery of Agricultural Products and Products is seen from what the understanding, duties, and rights and obligations of the expeditor Then as a repressive step that is behind the bill of lading it is mentioned that there are procedures to claim damage, loss and delay of delivery of goods, and thereafter shall be liable to sanctions in the form of damages for loss, loss, and delay in the delivery of goods in respect of quantities and other calculations agreed upon by both parties.
\end{abstract}

Keywords: Legal Protection; Expedition; Transportation of Agricultural Products; Sea Freight Law

\begin{abstract}
Abstrak
Penulisan ini mendeskripsikan dan mengkaji permasalahan mengenai bagaimana perlindungan terhadap perusahaan ekspeditur yang dimuat dalam perjanjian perjanjian pengangkutan laut. Tujuan penulisan ini adalah untuk mengetahui perlindungan hukum terhadap perusahaan ekspeditur yang dimuat dalam perjanjian pengangkutan laut. Teknik pengumpulan data adalah studi kepustakaan dengan metode pendekatan statute approach, instrumen penelitian ini yaitu Kitab Undang-undang Hukum Dagang, Undang-Undang Nomor 17 Tahun 2008 tentang Pelayaran dan peraturan perundanng-undangan terkait, serta dokumen-dokumen pengangkutan laut. Hasil penelitian menunjukan bahwa setiap perusahaan ekspedisi muatan kapal laut (EMKL) memiliki prosedur dan persyaratan dalam mengangkut barang melalui laut, perlindungan hukum terhadap perusahaan ekspeditur yang dimuat dalam perjanjian pengangkutan laut terdapat 2(dua) sifat yaitu preventif dan represif. Sebagai langkah preventif, perlindungan hukum ekspeditur dari pengiriman barang hasil dan produk pertanian dilihat dari apa pengertian, tugas, serta hak dan kewajiban ekspeditur kemudian sebagai langkah represif yaitu dibalik bill of lading tersebut disebutkan bahwa terdapat prosedur megenai klaim kerusakan, kehilangan, dan keterlambatan pengiriman barang, dan untuk selanjutnya akan diberikan sanksi berupa ganti kerugian atas kerusakan, kehilangan, dan keterlambatan pengiriman barang yang mengenai jumlah dan perhitungan lainnya telah disepakati oleh kedua belah pihak.
\end{abstract}

Kata Kunci: Perlidungan Hukum; Ekspeditur; Pengangkutan Produk Pertanian; Hukum Pengangkutan Laut

\section{A. Pendahuluan}

Kondisi geografis negara Indonesia sangat mendukung pertumbuhan buah kelapa dimana Indonesia memiliki garis pantai terpanjang di dunia, hal ini membuat Indonesia menjadi negara pengekspor kelapa tertinggi di dunia yaitu sebanyak 20,16\% (dua puluh koma enam belas per seratus). Indonesia merupakan eksportir kelapa dan sabut kelapa kedua terbesar di dunia setelah Filipina. Pada 2014, kontribusi Indonesia mencapai 20,16 persen dari total nilai ekspor dunia sebesar 1,21 miliar dollar AS (Kompas.com edisi 9 Februari 2017). Untuk mendistribusikan hasil produk 
pertanian di negara maritim atau negara kepulauan harus dilakukan pengangkutan yang terstruktur dengan baik, sehingga barang yang diangkut sampai ke tempat tujuan dengan selamat dan dalam waktu yang cepat.

Seiring dengan perkembangan metode perdagangan yang semakin maju, kini di Indonesia mulai banyak perusahaan penyedia jasa pengiriman barang atau ekspeditur. Pengangkutan merupakan kegiatan untuk memindahkan penumpang dan atau barang dari satu tempat ke tempat lain dengan selamat. Pengangkutan menurut Purwosutjipto adalah perjanjian timbal balik antara pengangkut dengan pengirim, di mana pengangkut mengikatkan diri untuk menyelenggarakan pengangkutan barang dan/atau orang dari suatu tempat ke tempat tujuan tertentu dengan selamat, sedangkan pengirim mengikatkan diri untuk membayar uang angkutan (Purwosutjipto, 1991:2). Pengangkutan niaga pada hakikatnya adalah menyewakan alat pengangkut kepada penumpang dan/atau pengirim barang, baik dijalankan sendiri ataupun dijalankan orang lain (Abdulkadir, 1998:13).

Untuk mendukung keberlangsungan perusahaan ekspeditur bekerjasama dengan pengusaha kapal atau pengangkut. Perkembangan usaha dalam bidang jasa pengangkutan yang mulai mendapat tanggapan positif dari perusahaan-perusahaan industri yang membutuhkan jasa tersebut untuk mengirimkan barangnya ke perusahaan lain atau ke konsumen, ternyata juga mengakibatkan terjadinya kasus-kasus yang pada dasarnya berkaitan dengan masalah pertanggungjawaban pihak pengangkut(Suwardi, 2011:18). Namun dalam pengoperasian, ekspeditur sering dirugikan baik materiil maupun immateriil atas keterlambatan pengiriman barang baik karena kealpaan maupun kesengajaan dari pihak pengangkut. Konsumen selalu menuntut pertanggungjawaban terhadap perusahaan pengirim (Ekspeditur) barang bukan kepada perusahaan jasa pengangkut.

Seperti contoh pada kasus PT Agility Internasional terhadap PT Indoexim Internasional 2015 silam, dalam kasus tersebut PT Agility Internasional dituntut oleh PT IndoExim Internasional karena keterlambatan pengiriman serta kerusakan barang yang di muat dalam peti kemas yang mana proses pengemasan barang tidak dilakukan oleh PT Agility tetapi pihak shipper yaitu PT IndoExim sendiri (Putusan Nomor 227/PDT.G/2014/PN.JKT.TIM). Kemudian kasus berikutnya kasus adalah terhambatnya pengiriman barang-barang logistik maupun hasil produk pertanian disebabkan oleh force majeur seperti tenggelamnya Kapal Motor Cahaya Nusantara yang mengangkut 50 (lima puluh) ton beras sejahtera dari Kota Merauke ke kampung Distrik Tubang, Kabupaten Merauke, Papua dan tenggelam di perairan Pulau Hebe (MetroMerauke.com pada Senin tanggal 9 November 2017).

Berdasarkankan uraian tersebut di atas, karya ilmiah ini bukan hanya membahas permasalahan mengenai pertanggungjawaban pengangkut saja namun disertai batas tanggung jawab atas risiko pengiriman barang oleh ekspeditur dimuat dalam perjanjian perjanjian pengangkutan laut.

\section{B. Metode}

Berdasarkan judul penelitian dan rumusan masalah penelitian yang digunakan termasuk dalam kategori penelitian hukum normatif, yaitu metode penelitian hukum yang dilakukan dengan meneliti bahan pustaka atau data sekunder belaka (Soerjono Soekanto, 2001: 13-14). Pendekatan yang digunakan dalam penelitian ini adalah pendekatan perundang-undangan atau Statute Approach. Pendekatan perundang-undangan adalah pendekatan yang dilakukan dengan menelaah semua undang-undang dan regulasi yang bersangkut paut dengan isu hukum yang ditangani (Peter Mahmud, 2004:24).

Teknik pengumpulan data yang digunakan adalah Studi Kepustakaan (library research) yaitu suatu pengumpulan bahan hukum tertulis dengan menggunakan context analisys. Teknik ini berguna untuk mendapatkan landasan teori dengan mengkaji, mempelajari, dan memberi catatan terhadap buku-buku, peraturan perundang-undangan, dokumen, laporan arsip, dan hasil penelitian lainnya yang berhubungan dengan masalah yang diteliti(Peter Mahmud, 2004:27).

Teknik analisis data yang dipergunakan dalam penelitian ini adalah analisa secara kualitatif dengan menggunakann model analisis interaktif. Analisa data disajikan berdasarkan konsep tertentu dalam kerangka teori yang telah diuraikan sebelumnya. Data yang diperoleh dalam obyek penelitian diolah dan dikonfirmasikan dengan opini dari reponden yang berkompeten yang sedang diamati. Berdasarkan paparan tersebut kemudian ditarik kesimpulan dan saran. Selain itu juga bermanfaat untuk memecahkan masalah-masalah yang telah disbutkan dalam rumusan masalah. Dengan demikian dalam penelitian ini terdapat model analisa yang meliputi : reduksi data, penyajian data, dan penarikan kesimpulan. 


\section{Hasil Penelitian dan Pembahasan}

\section{Teori Perlindungan Hukum}

Menurut Fitzgerald sebagaimana dikutip Satjipto Raharjo awal mula dari munculnya teori perlindungan hukum ini bersumber dari teori hukum alam atau aliran hukum alam. Aliran ini dipelopori oleh Plato, Aristoteles (murid Plato), dan Zeno (pendiri aliran Stoic). Menurut aliran hukum alam menyebutkan bahwa hukum itu bersumber dari Tuhan yang bersifat universal dan abadi, serta antara hukum dan moral tidak boleh dipisahkan. Para penganut aliran ini memandang bahwa hukum dan moral adalah cerminan dan aturan secara internal dan eksternal dari kehidupan manusia yang diwujudkan melalui hukum dan moral (Satjipto Raharjo, 2000:53).

Ada beberapa pengertian terkait perlindungan hukum menurut para ahli, antara lain: Menurut Satjipto Rahardjo, perlindungan hukum adalah adanya upaya melindungi kepentingan seseorang dengan cara mengalokasikan suatu kekuasaan kepadanya untuk bertindak dalam rangka kepentingannya tersebut (Satjipto Raharjo, 2003:121). Menurut Setiono perlindungan hukum adalah tindakan atau upaya untuk melindungi masyarakat dari perbuatan sewenang-wenang oleh penguasa yang tidak sesuai dengan aturan hukum, untuk mewujudkan ketertiban dan ketentraman sehingga memungkinkan manusia untuk menikmati martabatnya sebagai manusia (Setiono, 2004:3). Menurut Muchsin perlindungan hukum adalah kegiatan untuk melindungi individu dengan menyerasikan hubungan nilai-nilai atau kaidah-kaidah yang menjelma dalam sikap dan tindakan dalam menciptakan adanya ketertiban dalam pergaulan hidup antara sesama manusia (Muchsin, 2003:14).

Philipus M. Hadjon membedakan 2 (dua) sarana perlindungan hukum yakni yang bersifat preventif (pencegahan) dan dalam bentuk yang bersifat represif (pemaksaan), baik yang secara tertulis maupun tidak tertulis dalam rangka menegakkan peraturan hukum (Philipus M. Hadjon, 1987:29). Perlindungan hukum yang preventif bertujuan untuk mencegah terjadinya sengketa, yang mengarahkan tindakan pemerintah bersikap hati-hati dalam pengambilan keputusan berdasarkan diskresi. Perlindungan hukum yang represif bertujuan untuk menyelesaikan terjadinya sengketa, termasuk penangananya di lembaga peradilan.

\section{Risiko Pengangkutan Barang Melalui Kapal Laut}

Menurut Wiwoho, perjanjian yang terjadi antara mereka yang memiliki barang karena khawatir akan mengalami kerugian sebagai akibat pelaksanaan pengangkutan karena ancaman bahaya di laut dengan mereka yang mau menanggung kerugian itu di sebut perjanjian pertanggungan laut (Adnandaka Nurvigya,dkk, 2015:1995).

Pada barang hasil dan produk pertanian seperti kelapa, sayur, buah, beras, umbi, dan sejenisnya jika tidak sesuai dengan kualifikasi karantina dan tidak dapat dilanjutkan untuk diangkut, maka hal tersebut bukan tanggung jawab ekspeditur atau pengirim seperti dalam Pasal 4 angka 2 The Hague Rules bahwa cacat pengemasan dan juga tidak lolos dalam kualifikasi karantina barang karena hal tersebut bukan kewenangan dari ekspeditur, karena barang tersebut termasuk barang yang rentan mengalami pembusukan dan kerusakan didalam ruangan yang kedap udara dan berakibat pada penuruanan nilai pada barang tersebut. Oleh karena itu catatan pada dokumen pengangkutan berfungsi. Apabila barang hasil produk pertanian tersebut tanpa disertai catatan-catatan khusus dan akan dimuat dalam petikemas, akan di kategorikan ke dalam general cargo/barang umum tanpa perlakuan khusus. Hal ini peru dilakukan fumigasi atau nengelolaan khusus terhadap barang sebelum dimuat, dan secara otomatis akan membuat proses pemuatan barang ke atas kapal akan membutuhkan waktu yang lebih lama sehingga barang akan sampai pada tujuan dengan selamat namut mengalami keterlambatan atau tidak sesuai dengan tanggal yang ditentukan dalam perjanjian pengangkutan.

\section{Perlindungan Hukum Ekspeditur dalam Perjanjian Pengangkutan Laut}

Ekspeditur menurut Pasal 86 KUHD adalah: "Seseorang yang pekerjaannya menyelenggarakan pengangkutan barang-barang dagangan dan barang-barang lain di darat atau di perairan. la diwajibkan membuat catatan-catatan dalam register harian secara berturut-turut tentang sifat dan jumlah barang-barang atau barang-barang dagangan yang harus diangkut, 
dan bila diminta, juga tentang nilainya." Ekspeditur menurut Soegijatna Tjakranegara ialah orang yang berusaha untuk menyediakan/jasa usaha pengangkutan dan pengiriman barang (Soegijatna Tjakranegara, 1995:70). Dengan demikian, ekspeditur adalah perantara yang bersedia untuk melayani penumpang maupun angkutan barang. Sebagai perantara hubungan hukumnya didasarkan atas perjanjian, yang dibuat antara pemilik barang dengan melayani pengiriman barang lazimnya dinamakan perjanjian ekspeditie, berbeda dengan perjanjian yang dibuat antara pengangkutan dengan pengirim/pemilik barang. Sebagai pihak perantara, antar pemilik barang dengan ekspeditur, ekspeditur bertugas dan bertanggung jawab sebagaimana diatur dalam Pasal 86 sampai dengan Pasal 90 KUHD. Perjanjian tersebut disepakati bahwa ekspeditur bersedia mencarikan pengangkutan baik darat, laut, dan udara yang baik untuk pengiriman barang, dan bertindak atas namanya sendiri, hal ini sama dengan komisioner yang bertindak atas namanya sendiri.

Pengertian perjanjian yang didefinisikan dalam Pasal 1313 KUHPerdata adalah "Suatu perbuatan dengan mana satu orang atau lebih mengikatkan dirinya terhadap satu orang lain atau lebih" (terjemahan dari Pasal 1313 Burgerlijk Wetboek (BW) yang berbunyi "Eene overeenkomst is eene handeling waarbij een of meer personen zich jegens een of meer ender verbinden") (Purwosutjipto, 1981:2). Menurut Purwosutjipto, perjanjian pengangkutan adalah perjanjian timbal balik antara pengangkut dengan pengirim, diama pengangkut mengikatkan dirinya untuk menyelenggarakan penangkutan barang dan atau orang dari suatu tempat ke tempat tujuan tertentudengan selamat, sedangkan pengirim mengikatkan diri untuk membayar angkutan (Purwosutjipti, 1991:1).

Perjanjian pengangkutan yang dibuat antara pihak yang diangkut dengan pihak perusahaan pengangkutan, pada umumnya tidak tertulis, namun didukung oleh dokumen pengangkutan. Dokumen inilah yang digunakan sebagai bukti telah terjadinya perjanjian pengangkutan antara orang dan atau pemilik barang yang dikirim dengan perusahaan pengangkutan. Sebagai perjanjian, maka menimbulkan hak dan kewajiban secara timbal balik antara perusahaan yang menyelenggarakan angkutan dengan yang diangkut, yaitu penumpang dan/atau barang. Pihak pengguna jasa angkutan mempunyai kewajiban membayar biaya angkutan yang telah ditetapkan dan disetujui bersama, sedangkan pihak perusahaan penyelenggara angkutan mempunyai kewajiban untuk mengantar atau mengirim penumpang dan/atau barang yang diangkut sampai di tempat tujuan dengan tepat dan aman (Suwardi, 2011:22).

Fungsi B/L dianggap sebagai alat bukti dari adanya hubungan hukum antara pengangkut dan pemilik barang. Pemegang $B / L$ mempunyai hak dan kewajiban sebagaimana yang diatur di dalam B/L, walaupun perjanjiannya dibuat secara terpisah (Djafar Al Bram, 2011:33).

Berikut ini ada 10 (sepuluh) asas hukum perjanjian yaitu (Mariam Darus, 1994:108):

1) Asas kebebasan berkontrak;

2) Asas konsensualisme (persesuaian kehendak);

3) Asas kepercayaan;

4) Asas kekuatan mengikat;

5) Asas persamaan hukum;

6) Asas keseimbangan;

7) Asas kepastian hukum;

8) Asas moral;

9) Asas kepatuhan;

10) Asas kebiasaan;

Di dalam pengangkutan laut terdapat beberapa dokumen pengangkutan seperti yang telah di jelaskan dalam pembahasan sebelumnya. Menurut Pasal 1 huruf (b) The Hague-Visby Rules, yang di maksud kontrak pengangkutan adalah yang tercakup pada dokumen Bill of Lading atau dokumen lain yang serupa dengan Bill of Lading. Ketentuan mengenai Bill of Lading juga di atur dalam Hamburg Rules Bagian IV Pasal 14 sampai dengan Pasal 18, yang mana dokumen transportasi atau dokumen pengangkutan secara keseluruhan termasuk garansi, asuransi, dan pemesanan tercantum dalam dokumen Bill of Lading.

Bill of Lading di Indonesia di atur dalam Pasal 504 hingga Pasal 517 KUHD. Namun jika di lihat dalam Pasal 90 KUHD menyebutkan bahwa perjanjian antara pengirim atau ekspeditur 
dengan pengangkut atau juragan kapal di sebut dengan Surat Muatan. Perjanjian pengangkutan laut adalah apa yang di sebut dengan dokumen Bill of Lading atau Konosemen dan dokumen serupa dengan konosemen yaitu Surat muatan sesuai dengan Pasal 15 Hamburg Rules, Pasal 20 UCP 600, serta Pasal 90 KUHD. Mengenai ketentuan tentang pengajuan klaim atas kehilangan barang, kerusakan, dan keterlambatan menurut Pasal 19 Hamburg Rules penanganannya adalah mengikuti keterangan yang tercantum dalam dokumen pengangkutan, jika tidak ada keterangan yang tercantum dalam dokumen pengangkutan maka dianggap barang dalam kondisi baik. Oleh karena hal tersebut maka di dalam dokumen pengangkutan atau Bill of lading sudah memuat dan mencantumkan mengenai pengajuan klaim atau pertanggung jawaban atas risiko kehilangan, kerusakan dan keterlambatan pengiriman barang melalui laut.

Philipus M. Hadjon membedakan 2 (dua) sarana perlindungan hukum yakni yang bersifat preventif (pencegahan) dan dalam bentuk yang bersifat represif (pemaksaan), baik yang secara tertulis maupun tidak tertulis dalam rangka menegakkan peraturan hukum (Philipus M. Hadjon, 1987:29). Sebagai langkah preventif, Perlindungan hukum Ekspeditur dari pengiriman barang Hasil dan Produk Pertanian dilihat dari apa pengertian, tugas, serta hak dan kewajiban ekspeditur. Hal-hal mengenai Ekspeditur diatur dalam Kitab Undang-Undang Hukum Dagang dalam Pasal 86 sampai dengan Pasal 90 . Berdasarkan Pasal-Pasal yang mengatur tentang Ekspeditur dapat disimpulkan bahwa kewajiban ekspeditur dalam menyelenggarakan pengangkutan adalah ;

1) Membuat catatan-catatan (Note) ke dalam register harian secara turut tentang sifat, jumlah dan nilai (bila diminta) barang yang diangkut;

2) Menjamin pengiriman dengan rapi dan cepat;

3) Memilih sarana pengangkutan yang terbaik;

4) Menanggung kerusakan dan kehilangan barang sebab kesalahan dan keteledorannya, kecuali cacat barang itu sendiri;

5) Menanggung perantara ekspedisi yang digunakan;

6) Membuat catatan surat muatan ke dalam register harian.

Seperti isi dari pada Bill of Lading pada Pasal 15 Hamburg Rules, pentingnya data-data barang yang dikapalkan disertakan sebagai lampiran dari Bill of Lading. Mengingat asuransi yang dimiliki oleh Ekspeditur terkait dengan muatan pada umumnya adalah Asuransi P\&I (Protection and Indemnimity) Club, yang hanya akan mengganti kerusakan/kehilangan cargo/ muatan apabila Ekspeditur memang harus bertanggungjawab secara hukum untuk mengganti kerusakan/kehilangan cargo/muatan sesuai dengan klausa-klausa yang terdapat di balik Bill of Lading Ekspeditur. Di dalam klausa-klausa di balik Bill of Lading tersebut, terdapat pembatasan/ limitasi pertanggungjawaban pengangkut terhadap kerusakan/kehilangan barang, yaitu misalnya seperti dibalik Bill of Lading PT Meratus Line yaitu limitasi sebesar maksimum £100 per kemasan/ collie/unit, hal ini dikarenakan PT Meratus Line tergabung dalam P\&/ Club. Besarnya tanggung jawab $P$ and I Club atas tanggung jawab yang dihadapi perusahaan perkapalan (anggotanya) serta klaim-klaim yang bagaimana yang akan diperoleh dari klub diatur dalam ketentuan tersendiri yang disebut $P$ and I Rules. Jumlah klaim yang dibayar shipper hanya bisa diperolehnya dari klub kalau jumlah itu dibayar sesuai dengan kontrak pengangkutan. Oleh karenanya, klub pada umumnya selalu minta kepada pemilik kapal agar sebelum menyetujui suatu tanggung jawab kepada pihak lain memberitahukan hal tersebut terlebih dulu kepada Representatives dari $P$ and I Club setempat (Djafar Al Bram, 2011:62). Sebagai langkah represif, dibalik bill of lading tersebut disebutkan bahwa terdapat prosedur megenai klaim kerusakan, kehilangan, dan keterlambatan pengiriman barang, dan untuk selanjutnya akan diberikan sanksi berupa ganti kerugian atas kerusakan, kehilangan, dan keterlambatan pengiriman barang yang mengenai jumlah dan perhitungan lainnya telah disepakati oleh kedua belah pihak. Dalam pembuatan klausulaa mengenai sanksi ini menganut pada peraturan pemerintah, mengenai tarif atas pengangkutan dan ganti kerugian.

Lampiran dari Bill of Lading yang memuat mengenai asuransi pengiriman barang, sejauh mana ekspeditur dapat bertanggungjawab atas kerugian maupun kerusakan barang, dan kewajiban penerima barang tertuang dalam Commercial Invoice yang dikeluarkan oleh pengirim. Seperti dalam Bill of Lading Nomor MC8050145, yang berisi mengenai pengiriman barang produk kelapa dari PT Zakwan Agrindo Perkasa di Bandar Lampung ke Theppadungporn Coconut Co.Ltd, Soi Preecha, Maharaj Road Prabarom Maharachawan G Pranakorn, Bangkok 10200 
Thailand, Isi Commercial Invoice berdasarkan Commercial Invoice Nomor 55.INV.11.2017 adalah menerangkan seputar : Tanggal dikeluarkan Commercial Invoice; Deskripsi barang; Nama Penerima barang; Tanda pengiriman; Alamat Pelabuhan Debarkasi; Alamat Pelabuhan Embarkasi; Ketentuan Pembayaran; Ukuran Kontainer; Ukuran Barang; Harga per buah; Total harga disertai format kontrak perdagangan menurut International Commercial Terms (Incoterms); Asal barang; Alamat Bank untuk dilakukan pembayaran.

Dari keterangan tersebut untuk mengetahui batas-batas tanggungjawab pengirim/Shipper dan/atau ekspeditur serta penerima/Consignee dilihat dari keterangan total harga yang disertai format kontrak menurut Incoterms. Dalam Commercial Invoice Nomor 55.INV.11.2017 menyatakan pengiriman barang berupa buah kelapa sebanyak 52,110 KG dengan total harga sebesar USD 15,633.00, format kontrak adalah CIF:Bangkok. Yang dimaksud CIF:Bangkok adalah perjanjian jual beli buah kelapa ini menggunakan format perdagangan Cost, Insurance, and Freight (CIF) yaitu seperti dikutip pada International Comercial Tems tahun 2015 (Incotems 2015), "The seller must pay the costs of bringing the goods to the specified port. They also pay for insurance. The buyer is responsible for risks when the goods are loaded onto the ship." yang dimaksud CIF adalah penjual atau pengirim barang berkewajiban membayar tagihan mulai dari pengangkutan barang dari pelabuhan pengirim hingga ke pelabuhan penerima dimana dalam Invoice ini merupakan pelabuhan di Bangkok. Penjual atau pengirim barang juga berkewajiban membayar asuransi pengiriman barang. Pembeli atau penerima barang bertanggung jawab atas risiko ketika barang telah di muat keatas kapal hingga ke pelabuhan tujuan. Dari sekian format kontrak perdagangan dalam Incoterms 2015 tersebut memiliki kelebihan dan kekurangan. Dalam perlindungan barang dalam pengiriman melalui kapal laut harus disertai asuransi barang. Asuransi dalam hal ini perlu disepakati siapa yang akan menanggung dan membayar biaya asuransi guna mencegah kerugian akibat risiko-risiko yang terjadi. Dalam format ini yang menentukan secara jelas siapa yang akan menanggung biaya tersebut adalah CIF Kewajiban penjual untuk bertanggung jawab dibatasi hingga barang telah dimuat keatas kapal, namun biaya asuransi dan biaya pengangkutan telah di tanggung oleh penjual. Hal ini berarti Penjual atau pengirim atau ekspeditur telah memenuhi kewajiban, untuk risiko lain yang terjadi dalam pengangkutan serta kerugian akan di tanggung pembeli atau penerima barang.

Berdasarkan Pasal 27 UCP 600, mengatur tentang Clean Transport Document bank hanya akan memerima dokumen transportasi yang utuh atau bersih. Dokumen yang dimaksud adalah dokumen yang tanpa catatan atau klausulaa khusus yang menunjukan bahwa kondisi yang tidak efektif dari barang atau dari pengemasan barang. Kata "Clean" tidak perlu dituliskan dalam dokumen pengangkutan, tetapi jika memeng dibutuhkan maka dapat diberikan keterangan seperti "Clean On Board" pada dokumen pegangkutan. Mengenai kewajiban penjual atau dalam hal ini termasuk pengirim dan/atau kuasa pengirim atau ekspeditur dalam Pasal 30 United Nations Convention on Contracts for The International Sale of Goods (CISG) yaitu Ekspeditur berkewajiban untuk mengirim barang, mengurus dan menyerahkan dokumen terkait dan memindahkan segala perangkat pada barang seperti yang di sepakati didalam perjanjian dan juga dalam konvensi CISG. Hal ini dapat merujuk pada Incoterms 2015 format kontrak dagang mana yang di sepakati oleh kedua belah pihak. CISG telah menegaskan bahwa batas-batas tanggungjawab Ekspeditur beserta cakupan hak yang dapat dilindungi adalah berdasarkan format kontrak dari Incoterms 2015. Format kontrak CIF adalah format yang mengatur secara jelass mengenai batasan tanggungjawab ekspeditur dalam mengirim barang seperti yang telah dijelaskan di pembahasan sebelumnya.

\section{Simpulan}

Perlindungan hukum terhadap perusahaan ekspeditur yang dimuat dalam perjanjian pengangkutan laut terdapat 2 (dua) sifat yaitu preventif dan represif. Sebagai langkah preventif, Perlindungan hukum Ekspeditur dari pengiriman barang Hasil dan Produk Pertanian dilihat dari apa pengertian, tugas, serta hak dan kewajiban ekspeditur. Hal-hal mengenai Ekspeditur diatur dalam Kitab Undang-Undang Hukum Dagang dalam Pasal 86 sampai dengan Pasal 90. Kemudian sebagai langkah represif yaitu dibalik bill of lading tersebut disebutkan bahwa terdapat prosedur megenai klaim kerusakan, kehilangan, dan keterlambatan pengiriman barang, dan untuk selanjutnya akan diberikan sanksi berupa ganti kerugian atas kerusakan, kehilangan, dan keterlambatan pengiriman 
barang yang mengenai jumlah dan perhitungan lainnya telah disepakati oleh kedua belah pihak. Format kontrak dagang yang paling efisien perlindungan hukum bagi kedua para pihak baik pengirim/ ekspeditur, pengangkut, dan penerima adalah format CIF (Cost, Insurance and Freight), dikarenakan barang yang dikirim telah pasti diasuransikan dan kewajiban-kewajiban pihak pengirim/ekspeditur telah ditentukan serta dipenuhi sehingga apabila terjadi risiko-risiko dan kerugian dalam proses pengangkutan barang melalui laut sudah bukan tanggungjawab daripada ekspeditur/pengirim melainkan tanggungjawab pihak penerima dan/atau pengangkut barang.

\section{E. Saran}

Untuk mengoptimalkan kontrak pengangkutan laut yang pada dasarnya diserahkan kepada kesepakatan antara para pihak maka seharusnya para pihak lebih memahami betul isi dan klausula mengenai pembagian risiko dan tanggungjawab masing-masing pihak dalam perjanjian baik yang tertuang dalam bentuk nota perdagangan maupun perjanjian-perjanjian lain. Klausula-klausula dalam perjanjian juga harus berdasar hukum yang jelas seperti penggunaan format kontrak dagang yang harus berdasarkan Incoterms yang berlaku.

\section{Daftar Pustaka}

Abdul Kadir Muhammad. 2013. Hukum Pengangkutan Niaga. Bandung: PT Citra Aditya Bakti.

Djafar Al Bram. 2011. Pengantar Hukum Pengangkutan Laut (Buku I): Pengertian, Asas-Asas, Hak Dan Kewajiban Para Pihak. Jakarta: Pusat Kajian IImu Hukum Fakultas Hukum Universitas Pancasila (PKIH FHUP)

Mariam Darus Badrulzaman. 1994. Aneka Hukum Bisnis. Bandung: Alumni.

Muchsin. 2003. Perlindungan dan Kepastian Hukum bagi Investor di Indonesia. Surakarta: Disertasi S2 Fakultas Hukum, Universitas Sebelas Maret.

Peter Mahmud Marzuki. 2004. Penelitian Hukum. Surabaya: Kencana Pernada Group.

Phillipus M. Hadjon. 1987. Perlindungan Hukum Bagi Rakyat Indonesia. Surabaya: PT. Bina IImu.

Purwosutjipto. 1981. Pengertian Pokok Hukum Dagang Indonesia, Jilid I. Jakarta: Djambatan.

Djambatan

1991. Pengertian pokok Hukum Dagang Indonesia 3, Hukum Pengangkutan. Jakarta:

Satijipto Raharjo. 2000. Ilmu Hukum. Bandung: PT. Citra Aditya Bakti.

2003. Sisi-Sisi Lain dari Hukum di Indonesia. Jakarta: Kompas

Setiono. 2004. "Rule of Law”. Disertasi. Surakarta: Pascasarjana Fakultas Hukum, Universitas Sebelas Maret.

Soegijatna Tjakranegara. 1995. Hukum Pengangkutan Barang dan Penumpang. Jakarta: Rineka Cipta.

Soerjono Soekanto. 2001. Penelitian Hukum Normatif (Suatu Tinjauan Singkat). Jakarta: Rajawali Pers.

Adnandaka Nurvigya, dkk. 2015. "Menelaah Waktu Terjadinya Risiko (Kehilangan/Kerusakan Barang) dalam Praktik Proses Pegangkutan Laut". Jurnal Gema XXVII/50/Februari-Juli 2015. Surakarta: FH UNS

Suwardi. 2011. "Tanggung Jawab Pengangkut Akibat Keterlambatan Pengiriman Barang”. Jurnal Hukum. Vol XX, No. 20, April 2011. Surabaya: Fakultas Hukum Universitas Narotama Surabaya.

Artikel Ekspor Kelapa di Indonesia, pada situs berita Kompas.com edisi 9 Februari 2017. Diakses pada tanggal 4 Januari 2018 pukul 21.09 WIB

MetroMerauke.com pada Senin tanggal 9 November 2017 diakses pada tanggal 4 Januari 2018 pukul 16.00 WIB

Putusan.mahkamahagung.go.id diakses pada tanggal 30 Oktober 2017 pukul 22.00 WIB 